\title{
Notes on Equisetum debile, Roxb.
}

\author{
BY
}

\section{SHIV RAM KASHYAP.}

\section{With three Figures in the Text.}

\section{THE ENDODERMIS.}

$\mathrm{T}$ has long been known that the form and position of the endodermis 1 of the stem in the genus Equisetum is very variable. Three different types may be distinguished: (i) one endodermal ring round each vascular bundle, (ii) two layers of endodermis, one outside and the other inside the ring of vascular bundles as a whole, (iii) one endodermal layer round the ring of vascular bundles as a whole. These different types are not restricted to different species of the genus exclusively, but two may occur in different parts of the same plant. The following, for example, is the condition of the endodermis according to Sadebeck (vide 'Nat. Pflanzenfamilien'). In the internodes of the aerial shoots of $E$. Heleocharis the endodermis is of the first type; in E. hiemale, E.ramosissimum, E. trachyodon, and E. variegatum it is of the second type; and in E.palustre and E. scirpoides it is of the third type. In the internodes of the underground portion of the shoots of $E$. hiemale, E.ramosissimum, and E.trachyodon, however, the endodermis is of the first type, though in the aerial portion it is of the second type. In the internodes of the underground portion of the shoots of E. sylvaticum the endodermis is of the second type, though in the aerial portion it is of the third type. In most investigated species, however, according to Sadebeck, this difference in the aerial and underground portions of the shoot is not present, e.g. in E. arvense, E. maximum, E. palustre, E. scirpoides, $E$. Heleocharis, and $E$. variegatum; but in the underground tuberous swellings of $E$. palustre, $E$. arvense, and $E$. sylvaticum Pfitzer found an endodermis of the first type. ${ }^{1}$

If we do not take into consideration the exceptional case of the underground tuberous swellings of the three species mentioned above on account of their great modification, it is clear from the above description that in those species where two different forms of the endodermis occur in different parts of the stem, an endodermis of the first type is associated with the

\footnotetext{
1 For further details see Engler and Prantl: Nat. Pflanzenfamilien.
} 
endodermis of the second type, and an endodermis of the second type is associated with one of the third type. Since underground organs, e.g. the root of vascular plants, retain their ancestral structure for long periods and through many phyla, it appears that an endodermis of the second and the third type has been gradually derived from that of the first type. This view is borne out by the writer's observations on the endodermis of $E$. debile. $E$. debile is the most variable species of the whole genus as regards the form of the endodermis in the stem. In a very general way it may be stated that in the internode of the underground rhizome the endodermis belongs to the first type ; in the aerial vegetative shoot it is of the first type near the node but of the second type in the internode; and lastly in the fertile shoot

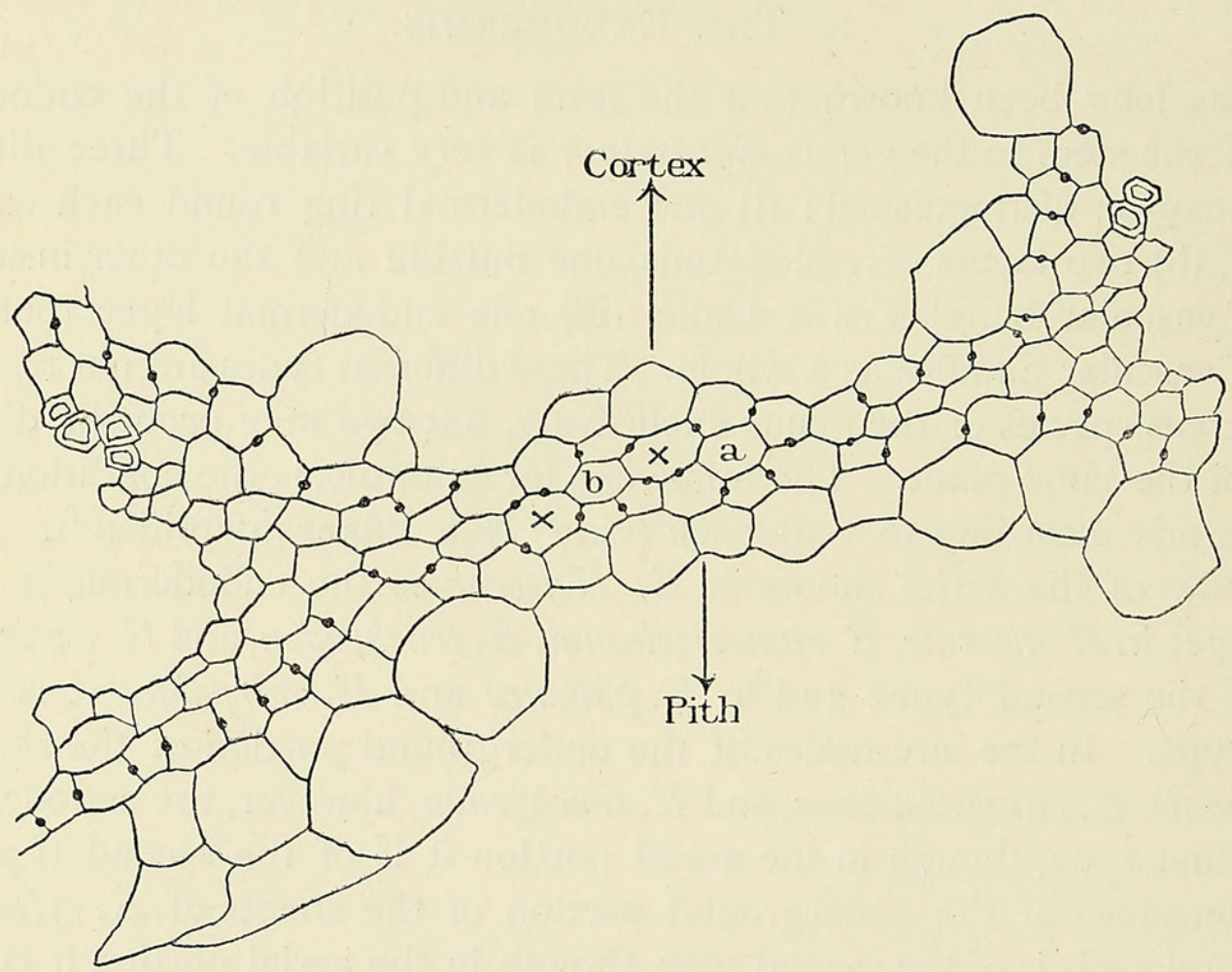

FIG. I. Equisetum debile. (For explanation see the text.)

below the cone as well as in the cone, so far as it can be traced upwards, it is of the first type. At the same time, in the internodes of the underground as well as the aerial portions, the two types, first and second, merge into each other. The transition is met with at all places in the internode irrespective of its nearness to the node. In those species where two layers of the endodermis occur, one external and the other internal to the ring of the vascular bundles, the band of parenchyma lying between the two layers in the interfascicular region is usually very narrow owing to the external endodermis being bent inwards in that region. In Equisetum debile these two layers are actually fused in certain places so that a complete closed ring of endodermis is formed, not only round one or more bundles, but isolated rings of endodermis are also pinched off in the interfascicular region, pro. 
ducing small islands of parenchymatous tissue of one to six or seven cells. These isolated rings may be close to each other so that one cell is actually common to the two rings (Fig. I, $\times$ ), or the endodermis round the parenchymatous cells may be quite independent (Fig. 2, $a$ ). In Fig. I the two rings $a$ and $b$ are connected by one cell having suberized bands on four of its walls, two belonging to one ring and two to the other. In other cases two of the bands may actually occur on one wall, the four bands belonging to two rings occurring on three walls as seen in Fig. 3 at $a$.

It is easy to understand the formation of these islands if we suppose that the second type of the endodermis is gradually passing into the first by the fusion of the two layers at various points. But that is hardly likely in view of what has been said and what is to follow. It is more difficult to understand how these islands could be formed if the endodermis of the first

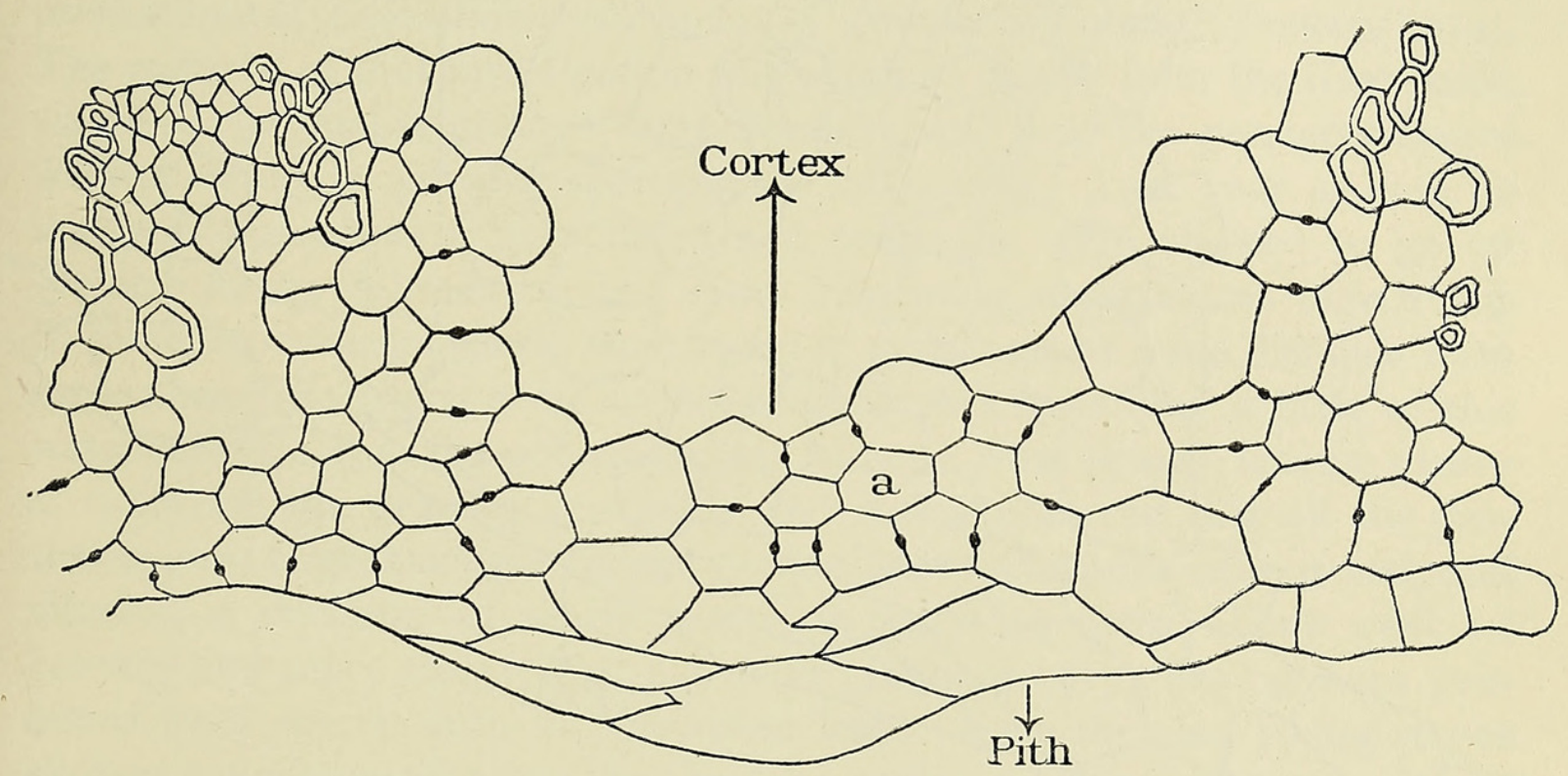

FIG. 2. Equisetum debile. (For explanation see the text.)

type at the node is giving rise to the endodermis of the second type in the internode.

In the aerial fertile region below the cone, and in the base of the cone itself, the endodermis is of the first type everywhere. It may be due to the fact that the internodes here are very short. Since the fertile part of the shoot, however, is known to be more conservative and retains its ancestral structure for a longer time than the vegetative shoot, it is likely that this arrangement indicates the ancestral features of the stem, especially when taken along with the structure of the rhizome. In the cone itself, even near its base, the characteristic bands on the radial walls of the endodermis are lost, but the layer can be distinguished on account of the large size and regular arrangement of the cells. As we ascend higher, however, even these 
distinctive characters gradually disappear and the endodermal cells can no longer be distinguished from the neighbouring parenchymatous cells.

In the region of the hypocotyl in the young plant the changes in the form of the endodermis are as follows: The root is usually triarch without pith and with an external endodermis having suberized bands on radial walls. Higher up some parenchymatous pith appears in the centre and phloem comes to lie all round the xylem ring, as seen in a transverse section, and has a surrounding endodermis. At this stage a small bundle is given

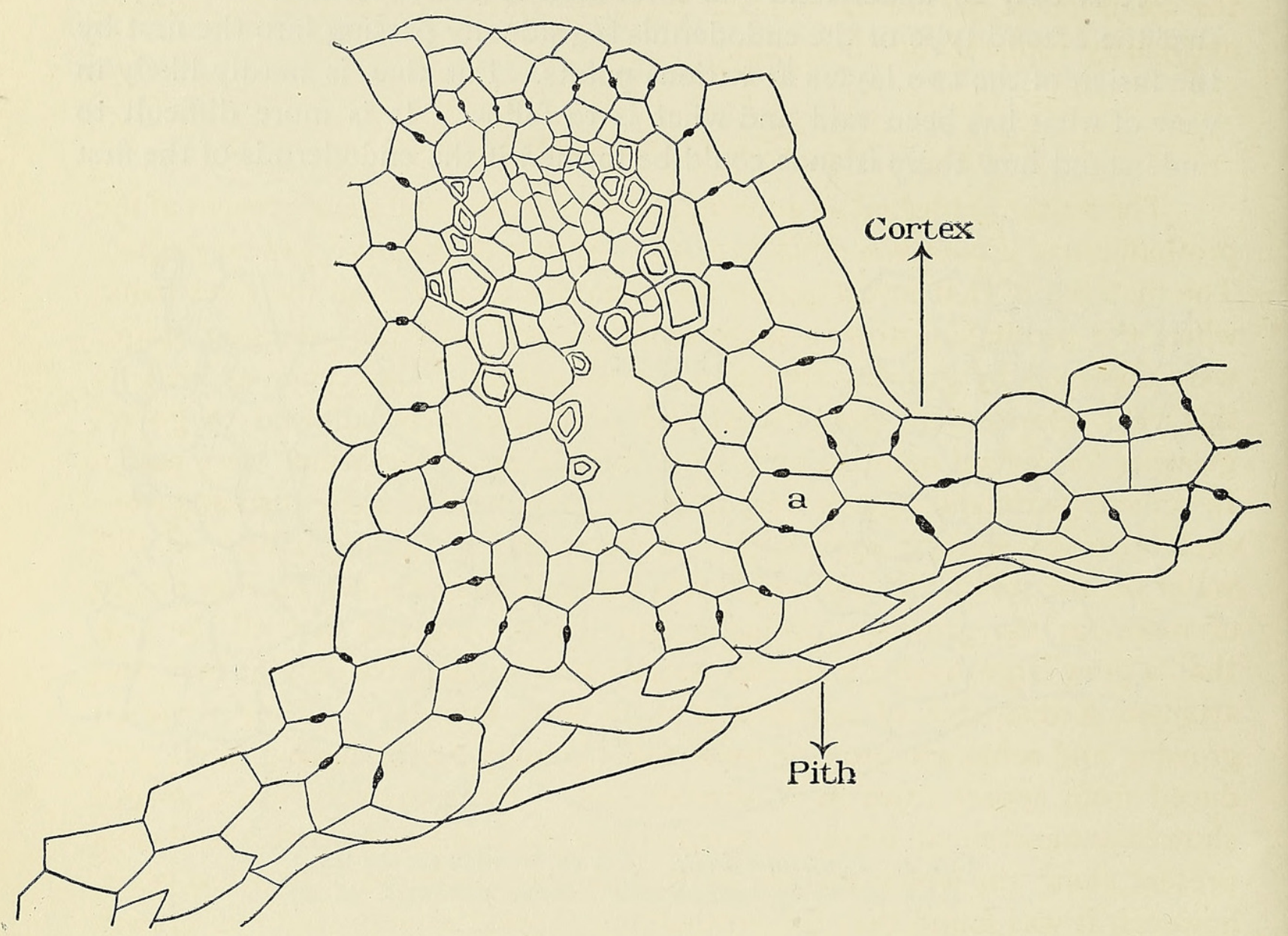

FIG. 3. Equisetum debile. (For explanation see the text.)

off for a branch, leaving a gap in the stele. A little higher the gap is closed. Then the three leaf-traces are given off for the first three leaves and the main stele also becomes separated into a few bundles (usually three). External endodermis here cannot be made out, though it becomes distinct a little higher up on the outside of the bundles only, but a little later it becomes continuous. At this place the internal endodermis appears as a small ring surrounding sometimes a single cell, or may be represented by a single cell with all its walls having suberized bands. Gradually the internal ring becomes wider and both layers persist up to the growing point. Thus, in the hypocotyl the internal endodermis forms an inverted cone, gradually 
tapering downwards and disappearing first above the origin of the first leaftraces. In other words, considered from below, it arises immediately after the giving off of the first leaf-traces. Each of these leaf-traces, like the traces higher up in the adult stem, have their own endodermis.

The significance of the islands of parenchyma surrounded by endodermis is not quite clear. Probably they represent vestiges of bundles which have gradually disappeared owing to the habitat of the plant, which is generally swampy soil. It is interesting to compare in this connexion the condition of the normal vascular bundles, which are also greatly reduced and partly replaced by air-spaces.

\section{The Prothallium.}

The writer published an account of the structure and development of the prothallium of Equisetum debile in I9I4 ('Annals of Botany', January I9I4). The material of that investigation was obtained chiefly from the river bank, where the prothallia grow in large numbers, and only the youngest stages were observed by growing spores in the laboratory. Last year as well as this year spores were germinated and prothallia were allowed to go on growing for several months, and some interesting observations were made. In some experiments spores were made to germinate at some distance from each other (by shaking some spores in water and sprinkling a little of this water on the soil in the pot, which was watered from below), leaving plenty of room for the growing prothallia, and it was observed that all the prothallia grew large, having a circular outline, bore archegonia only at first, and attained a diameter of nearly $2 \mathrm{~mm}$. in forty-five days. They went on growing and some are growing even now (January I9I7), having been produced from spores sown in November last. Even the very young stages showed a meristem all along the circular margin, and this meristem is always present along the whole margin in the bigger specimens. In a few cases, however, it was found that the prothallium showed a more vigorous growth on one side and the meristem was localized on a part of the margin. This was probably due to the mode of germination, owing to the spore having formed a short filament first, while in the other case it formed a mass of cells. Even in those cases where the meristem was localized on a part of the margin in the young stage, it would have gradually spread to the rest of the margins also, as shown by some other specimens which were a little older.

In other experiments the spores were grown thickly. In these it was observed that the prothallia grew in thick clusters and remained very small even after two to three months. They showed a distinctly apical growth and the meristem was restricted to one part of the margin. Naturally the prothallia were elongated antero-posteriorly, and the largest were about one 
millimetre in length and considerably less in width. They bore archegonia or antheridia. The occurrence of antheridia alone on the prothallia is interesting, as they are never found alone in the prothallia, growing at a distance from each other in the laboratory or in the wild state. In the latter state the prothallia are always scattered, clusters never having been observed. In the scattered prothallia archegonia are always formed first and antheridia arise only on the older prothallia. The prothallia arising in clusters from thickly sown spores are thus extraordinarily similar to those of other species of Equisetum figured by Buchtien and others. The lobes, however, in the prothallia of Equisetum debile are always erect in whatever condition the prothallia may be growing, thus differing from the lobes of those of other species which are spreading. It is possible that in some cases at least the prothallia of other species of Equisetum remain small owing to the spores having been sown thickly. It would be interesting to find out the behaviour of the spores of some other species of Equisetum when sown far apart.

It may also be mentioned that though in nature the prothallia do not last more than a few months, dying before the end of April, it is possible to keep them growing for a longer time, and perhaps for some years. The stoppage of growth and ultimate death is apparently due to two causesthe formation of the embryo and the heat of the summer. During I9I $5^{-16}$ some prothallia were kept in a glass-house from September I9I 5 to July 1916. The embryos as they were developed were cut away and the prothallia were protected from the heat in the glass-house. Thus they had been living for three months more than their ordinary life when unfortunately all the flower-pots containing them were submerged under water during a heavy downpour of rain and the prothallia were all killed. During the last two months of their existence the growth was very slow and parts of the prothallia died, leaving separate lobes growing independently. They would have very likely resumed their active growth in September again if they had lived up to that time.

\section{SUMMARY.}

I. The endodermis. The endodermis in Equisetum debile is very unstable. At the nodes of the underground and aerial sterile shoot and in the fertile region the endodermis surrounds each vascular bundles separately. In the internodes of the underground and aerial sterile shoots there is a transition from the separate endodermis round each bundle to two endodermal layers, one external and the other internal, round the ring of bundles as a whole. This transition is independent of the distance from the node of that part of the internode where it occurs. The two rings of endodermis fuse here and there, leaving islands of parenchymatous tissue in the interfascicular region. At the point of junction of the two layers a 
single cell may show radial bands on three or four of its walls or two bands on the same wall.

2. The prothallium. If the spores are sown thickly the prothallia remain small and show one growing point only and usually bear only one kind of sex organ. If the spores germinate at a distance from each other, leaving enough space for the prothallia to develop fully, the latter become very large and develop a meristem all round on the circular margin. ${ }^{1}$ It is possible to keep the prothallia growing for a few months longer than their natural period of life by removing the embryo and protecting the prothallia from heat, and probably possible to keep them growing for more than one year.

1 These prothallia bear archegonia at first and develop antheridia later on. 


\section{$2 \mathrm{BHL}$ Biodiversity Heritage Library}

Kashyap, Shiv Ram. 1917. "Notes on Equisetum debile, Roxb." Annals of botany 31, 439-445. https://doi.org/10.1093/oxfordjournals.aob.a089656.

View This Item Online: https://www.biodiversitylibrary.org/item/232813

DOI: https://doi.org/10.1093/oxfordjournals.aob.a089656

Permalink: https://www.biodiversitylibrary.org/partpdf/320199

\section{Holding Institution}

Smithsonian Libraries

\section{Sponsored by}

Biodiversity Heritage Library

\section{Copyright \& Reuse}

Copyright Status: Not in copyright. The BHL knows of no copyright restrictions on this item.

This document was created from content at the Biodiversity Heritage Library, the world's largest open access digital library for biodiversity literature and archives. Visit BHL at https://www.biodiversitylibrary.org. 